This report was prepared as an account of rork sponsnred by an ageecy of the United States Government. Nejber the Uaited States Government nor any ageacy thereof, nor ady of their employes, makes any parranty, express or implied, or essumes any legal liability or responsi. bility for the sceuracy, completerses, or usefulness of any information, apparatus, product, or proces diselosed, of represents that its use would nat infringe privately owned rights. Reference berein 10 any specifint commercial produch, proces, or setviee by trate name, enademark, monufacturer, or otherwise does not necessarily constitute or imply ils endorsemeat, recommendation, or favoring by the United States Government or any agency thereol. The views and opinions of authors expressed herein do not nesessarily state or reflect those of the Uaited States Gorerameat or any agency thereor.

\title{
Support Structures for Optical Components in the Laser Demonstration Facility
}

\section{Milestone Report 4014}

January 25,1985

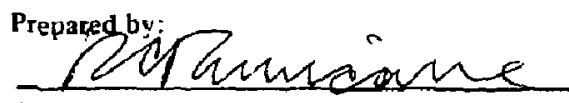

R. C. Finucane

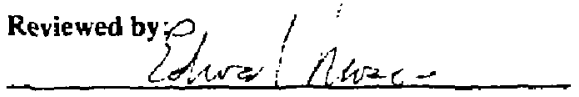

E. I. Moses, Laser Isotope Separation Associate Program Leader

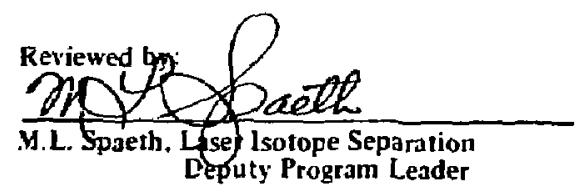

Approved by:

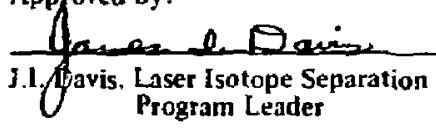

\section{LAWRENCE LIVERMORE NATIORSAL LABORATORY University of California · Livermore, California - 94550}


The laser system in the Laser Demonstration Facility is mounted on an array of 108 support columns. This milestone report describes the design, analyses, testing, faorication, installation, and performance characteristics of these supports.

\section{DESIG:4}

For manufacturing simplicity, all 108 support s have a similar design, with minor modifications depending on whether the : ructure supports a copper laser, a dye-laser component, or an optical omponent. Each support is a rectangular steel tube fabricated from half-in.' ASTM A-36 steel plate and rilled with concrete after erection. Supports are $22 \mathrm{ft}$ high, 1.5 it deep, and 4 or 5.2 ft wide (see Figs. 1 and 2).

The supports are arranged throughout the building as shown in Fig. 3 . In the copper laser bay, the supports are $4 \mathrm{ft}$ wide and arrayed on $8 \mathrm{ft}$ centers, leaving $4 \mathrm{ft}$ gaps for support columns of the mezzanine fioor, for air conditioning ducts to the first floof, and for vertical utility risers to the copper lasers.

In the dye and optics corridors, the supports are closely spaced, forming walls of nearly continuous optical surfaces (Fig. 3a). Some supports were more widely spaced to leave room for columns to support the mezzanine. After these mezzanine columns were installed, the gaps between the widely spaced supports were bridged by half-inch steel plates, so that optics could be installed at any location along the wall. 


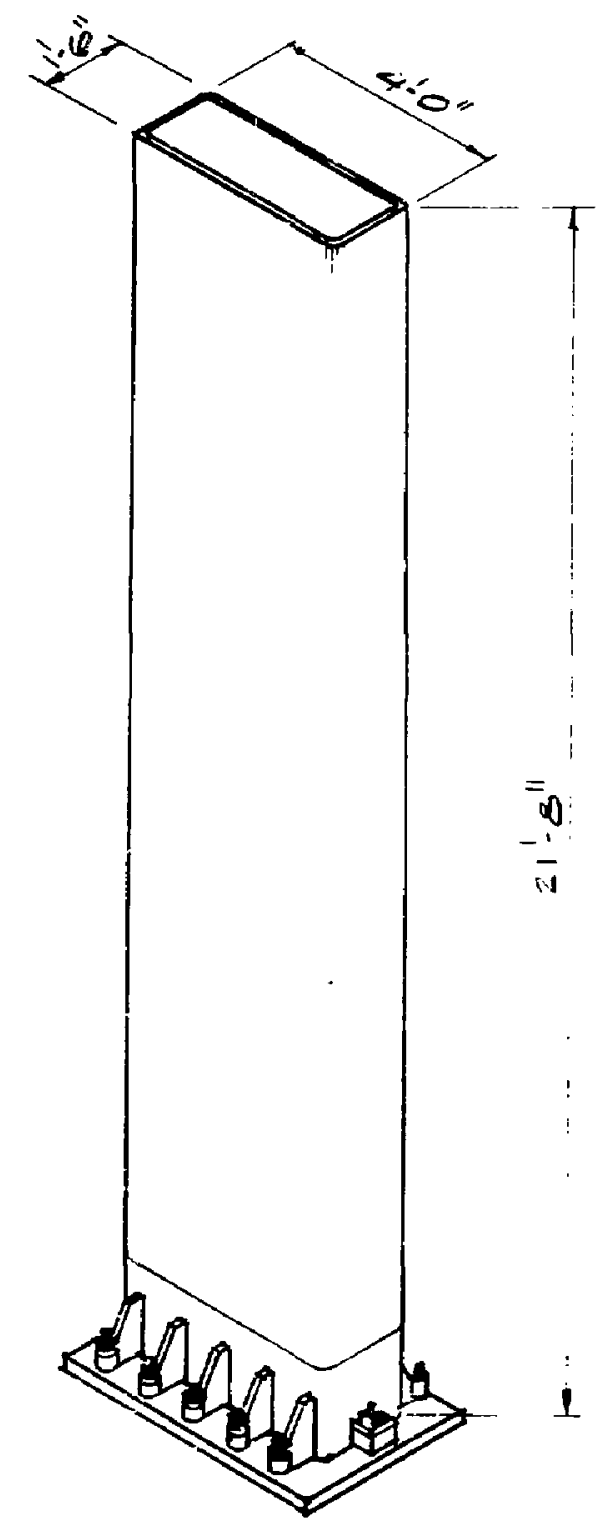

Fig. 1. Optical support structure for copper lasers. 


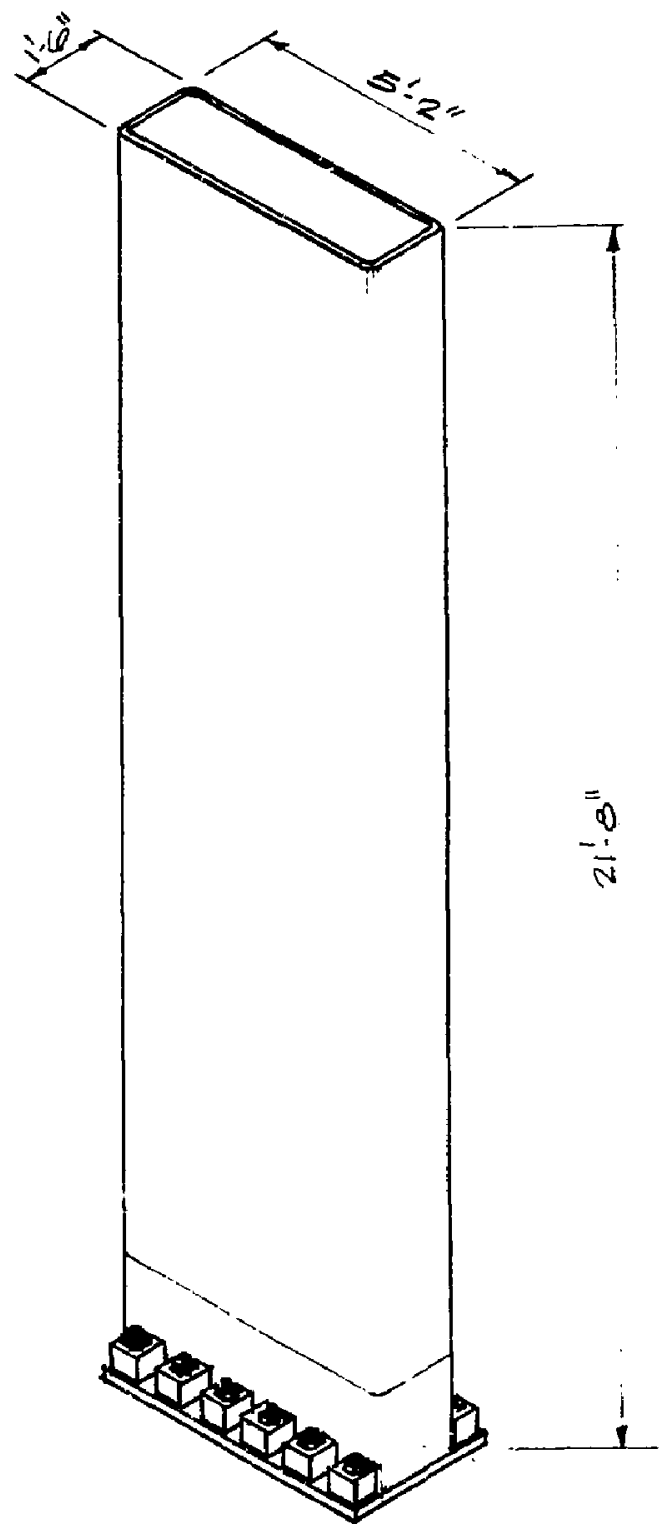

Fig. 2. Optical support structure for dye lasers. 

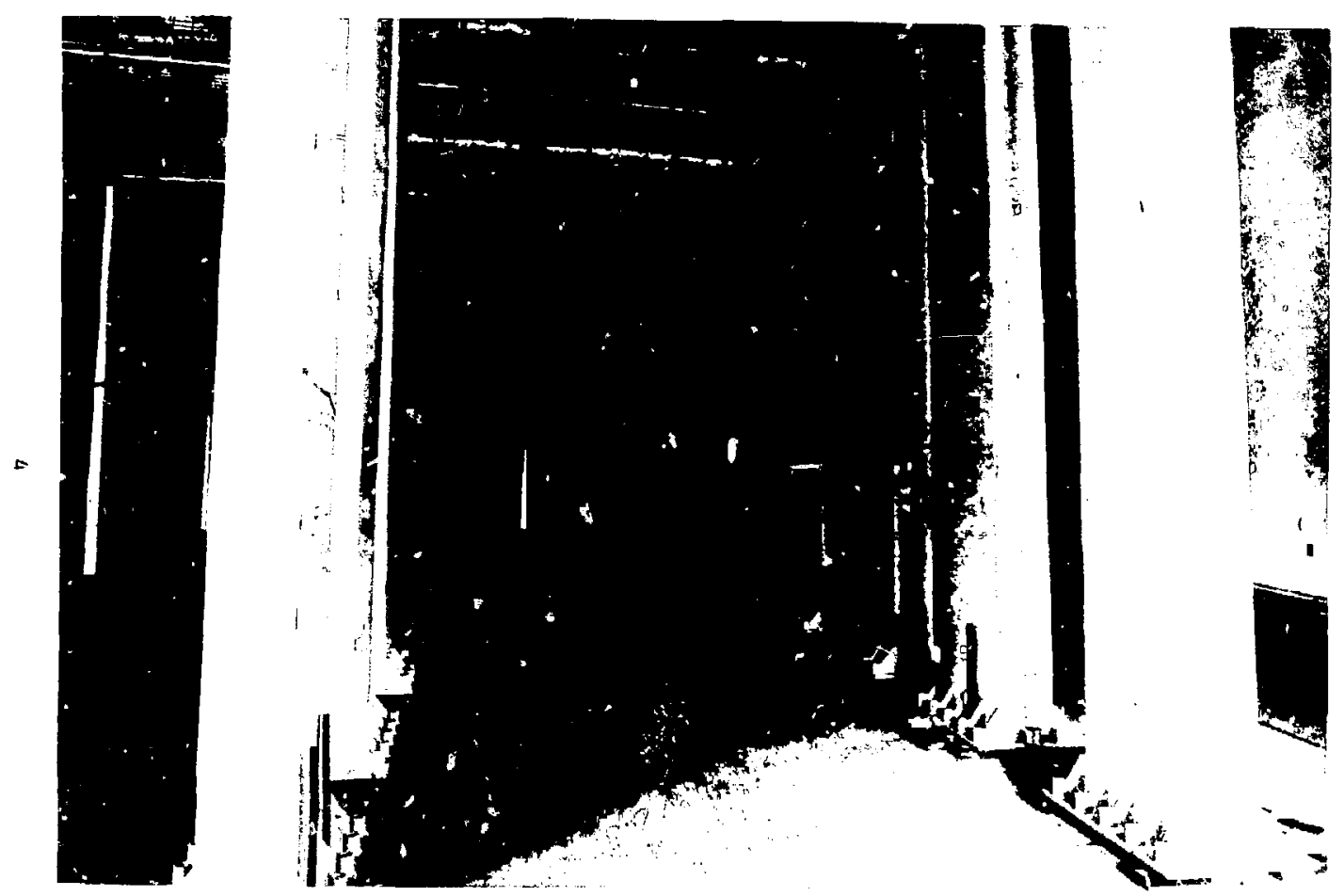

Fig. 3. Typlcal arrangement of supports in the laser bay. The supports are bolted to a monolithic iriertia-pad founuation. 


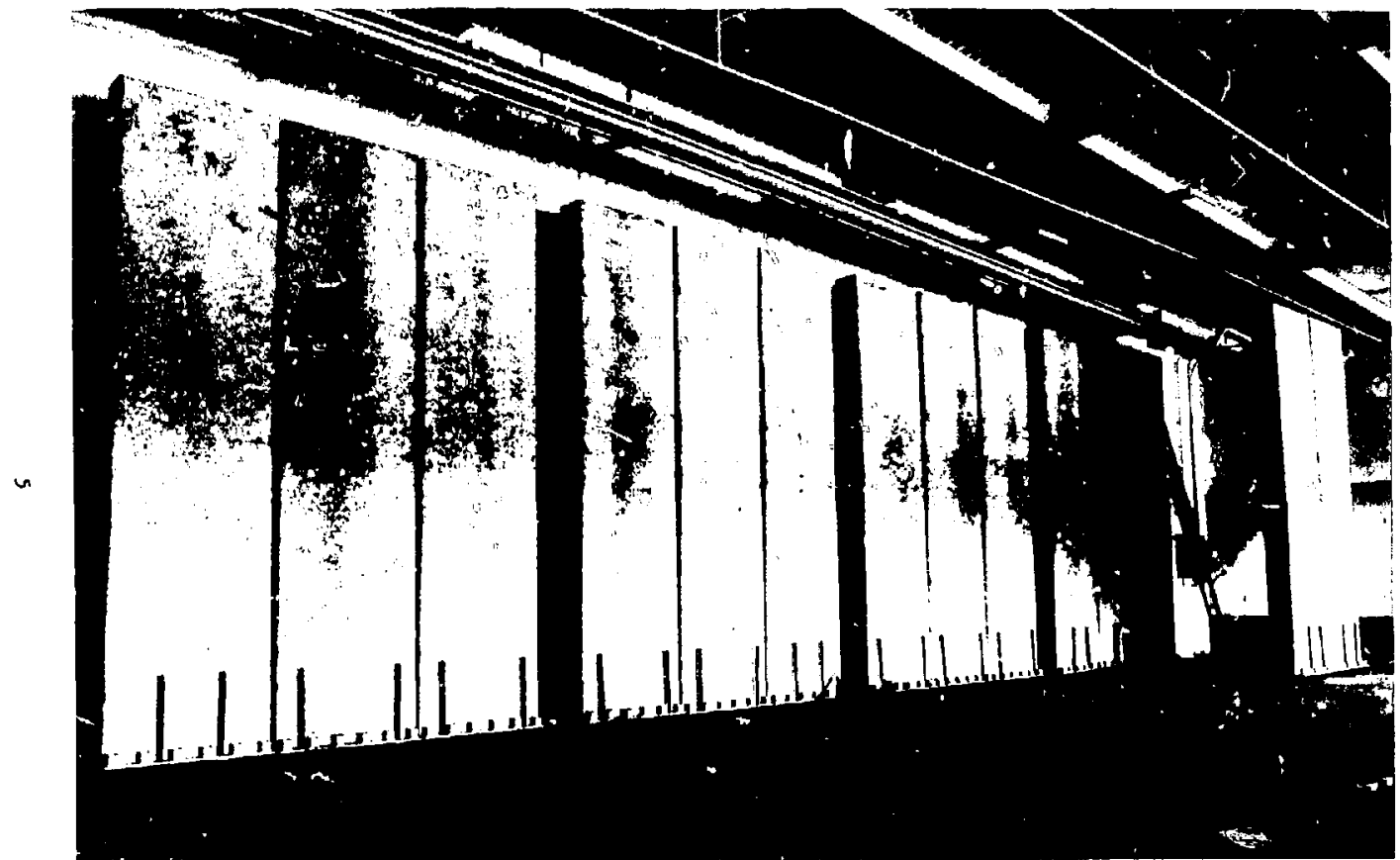

Fig. 3a. Typical arrangement of supports in the dye and optics corridors. The wider spaces allowed later installation of support columns for the mezzanine floor. 


\section{SEISMIC RESPONSE}

Because of the high value of the laser system, the optical support structures were designed to stringent seismic design criteria, satisfying both the 1982 Uniform Building Code and the LUINL 1000-year return-period Design Basis Earthquake. Two steps of analysis and design were required.

The first step was analysis and design as required by the Uniform Euilding Code 1982 Edition (UBC), with an additional seismic load factor of 1.5 on connections. The laser supports are classified as elements of a structure with a corresponding horizontal force factor of $0.3 \mathrm{~g}$. The allowable stresses for this design step are consistent with the UBC.

The second design step required a dyramic analysis for the LLNL Design Basis Earthquake. This sdrthquake has a $0.5-\mathrm{g}$ horizontal peak ground acceleration coupled with a $0.33-g$ vertical peak ground acceleration. A response spectrum defines the frequercy content and accelerations of this earthquake. Since the dynamic stresses do not exceed the elastic limits of the respective materials, a damping value of $5 \%$ of critical damping was selected.

A steel shell with a composite concrete core was selected as the structural system. This would give the tall vertical cantilevers excellent rigidity, ample strength, and enough mass to be relatively insensitive to transient vibrations. An elastic design method, similar to the working stress design method, was used to proportion the laser support structures. For this load case, the allowable stresses were limited to $90 \%$ of the steel's yield strength and $70 \%$ of the concrete's ultinate strength. 
3. MOUNTING DESIGN

Structually, the supports are considered to be 22-ft cantilevered composite vertical colums supported by a 3-ft-thick isolated reinforced concrete pad. Each column is grouted in place at its base and bolted to the pad with 3-ft-long high-strength steel bolts epoxied into hole:s drilled into the cancrete pad. The bolts are 1.25 in. diameter (nominal), full-thread, ASTM A-354 Grade BD, embedded $2 \mathrm{ft}$ into a 2-in. diameter hole. An ultimate strength test program was carried out to measure the pullout capacity of the bolts. $^{2}$ (See Fig. 4). The ultimate load capacity of the bolts was found to be 145,000 ib each, providing a safety margin of $2: 1$ during the 1000-year return-period Design Basis Earthquake.

4. FABRICATION AND INSTALLATION

Conventional construction contractors, selected by competitive bid, fabricated and installed the supports and filled them with concrete. To minimize dolivery time, the supports were fabricated at two separate industrial facilities. Standard welding construction tolerances were used ( $\pm 1 / 4$ inch). Inspectors hired by LLNL rejected three supports during fabrication.

The structures were trucked to the site, unloaded, and set in place using a forklift and winch (Figs. 5 and 6 ). Three-foot-long threaded steel bolts were then installed into predrilled holes and epoxied in place. Following final alignment and inspection (Fig.7), grout was pumpes beneath each support and allowed to cure. Each bolt was then stretched to 80,000 lbs tension, and the nut tightened to final preload of 70,000 lbs. Finally, each support was pumped full of concrete. 


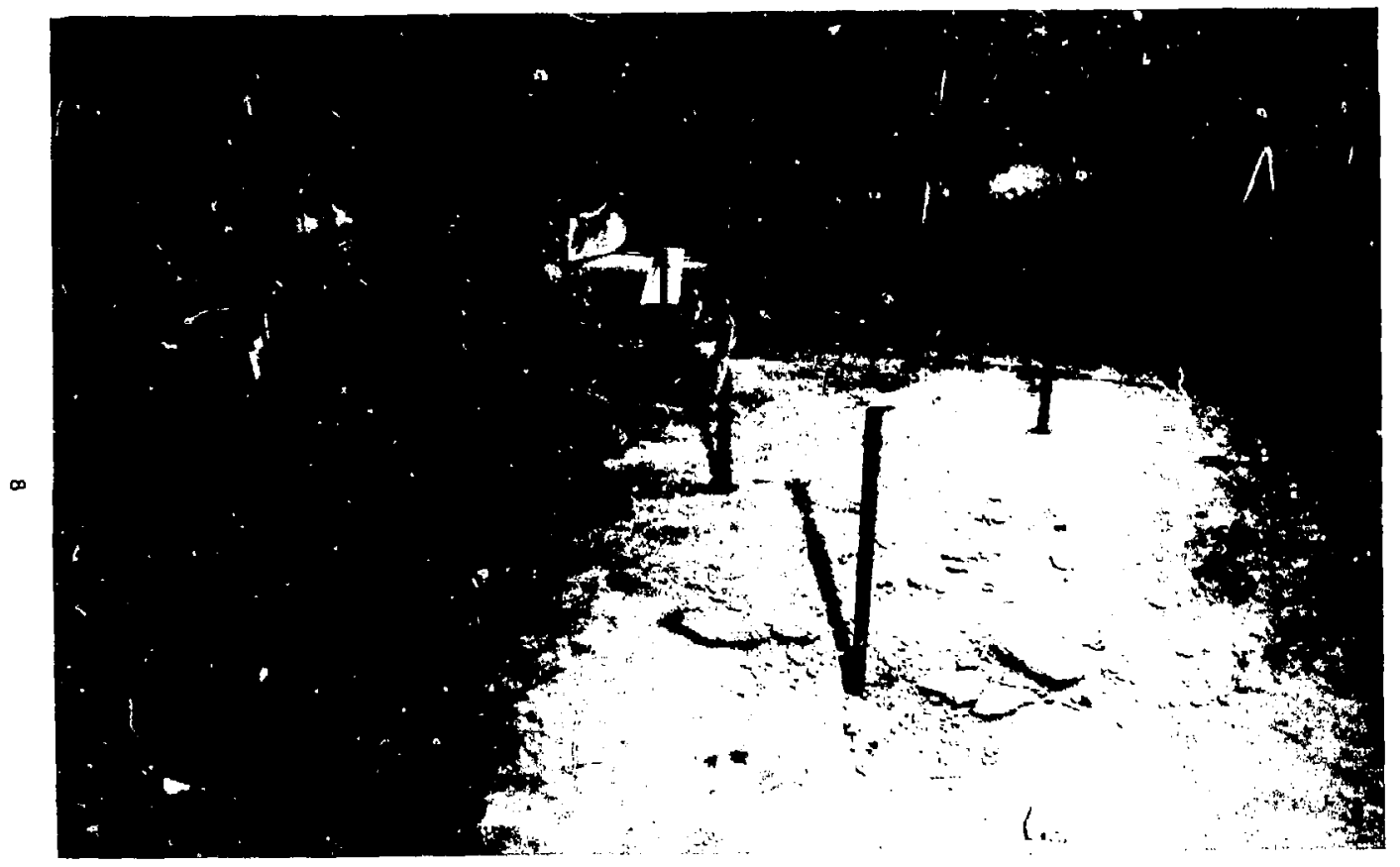

Fig. 4. Test program roon where ultimate pullout stress of bolts was determined. The nearest volt pulled out at 145 , 000 lo. 


$$
\Lambda
$$




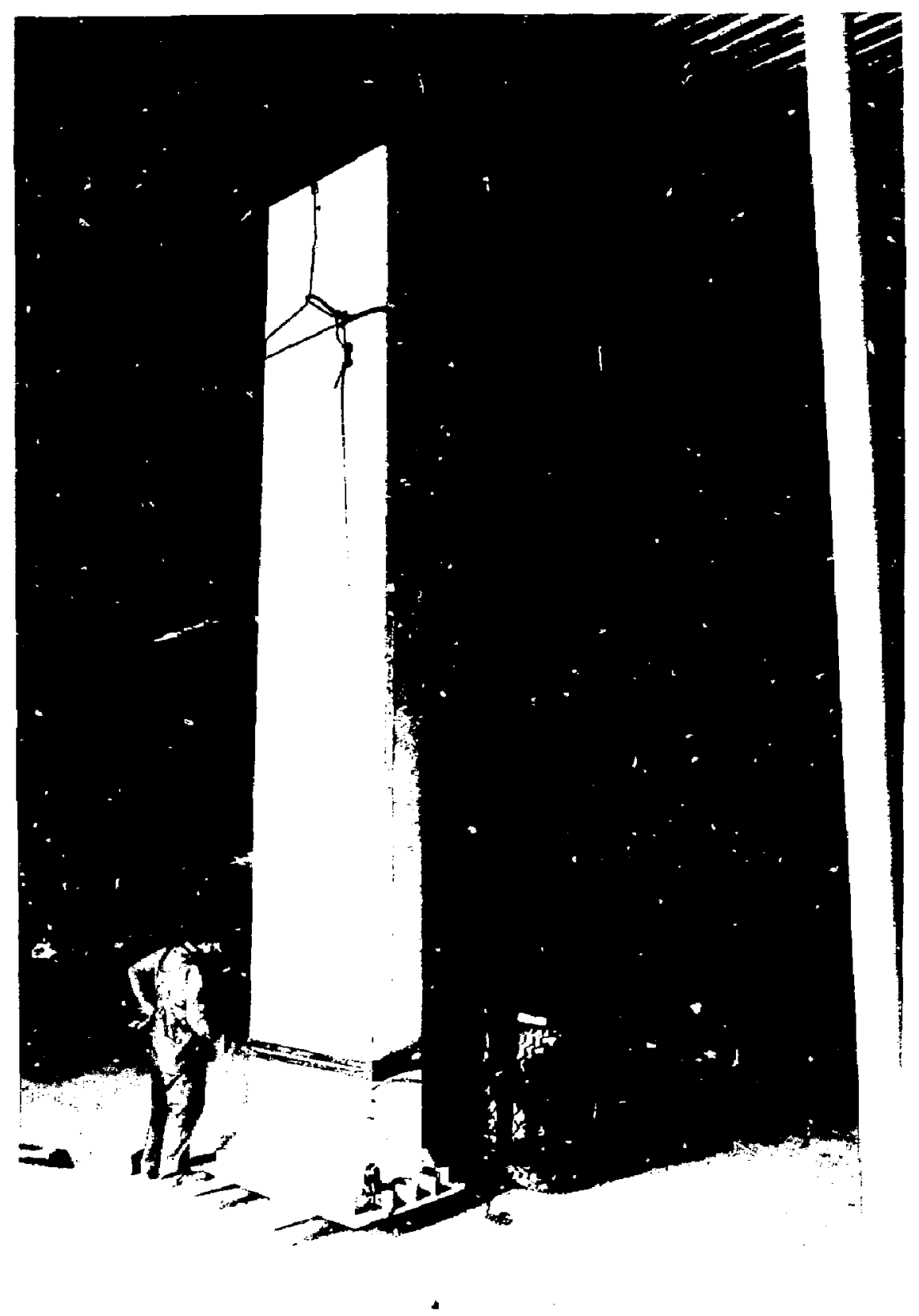

Fig. 6. A support secured on a forklitt for transporting to its final position. 


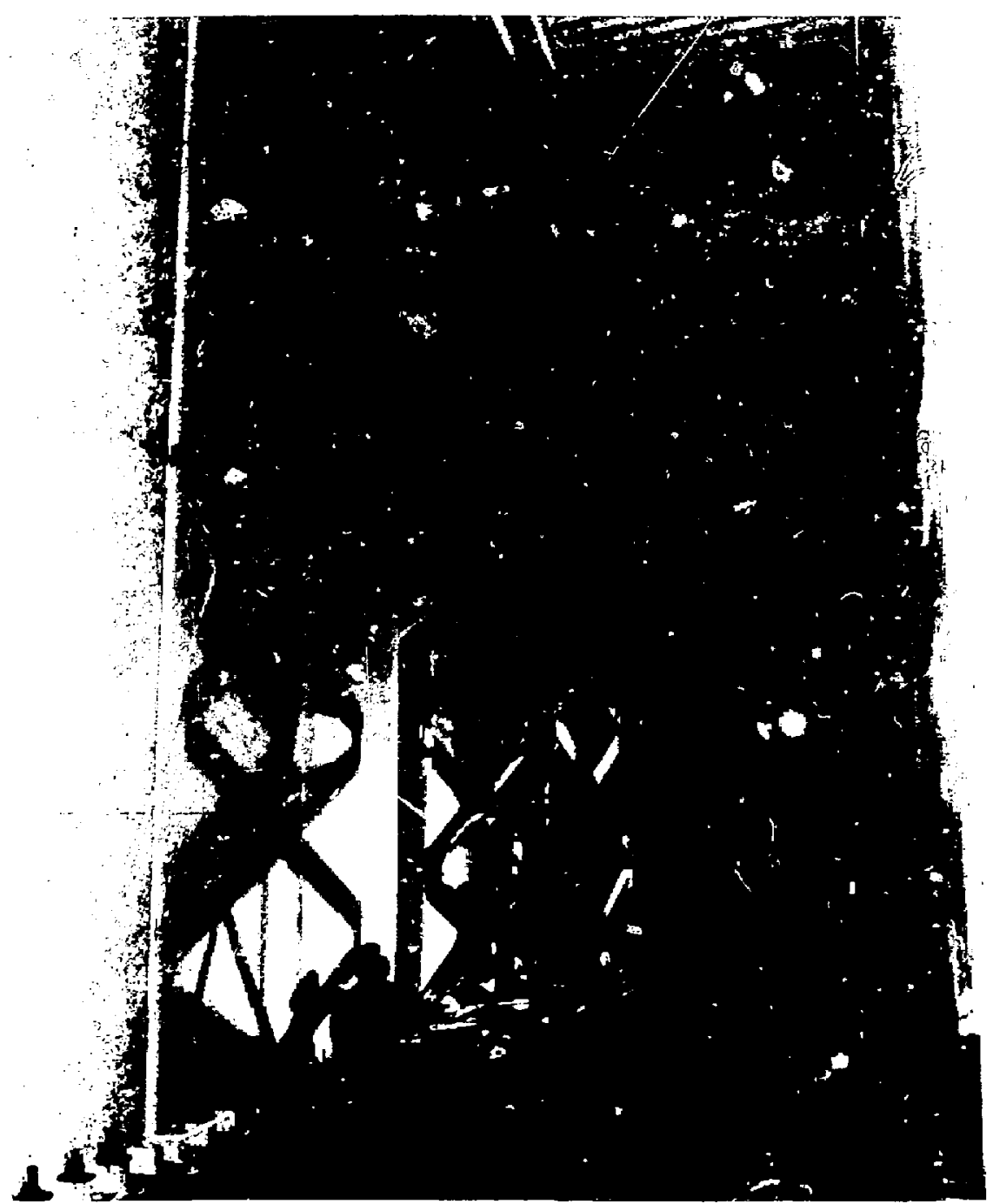

Fig. 7. Finel alignment and inspection. 


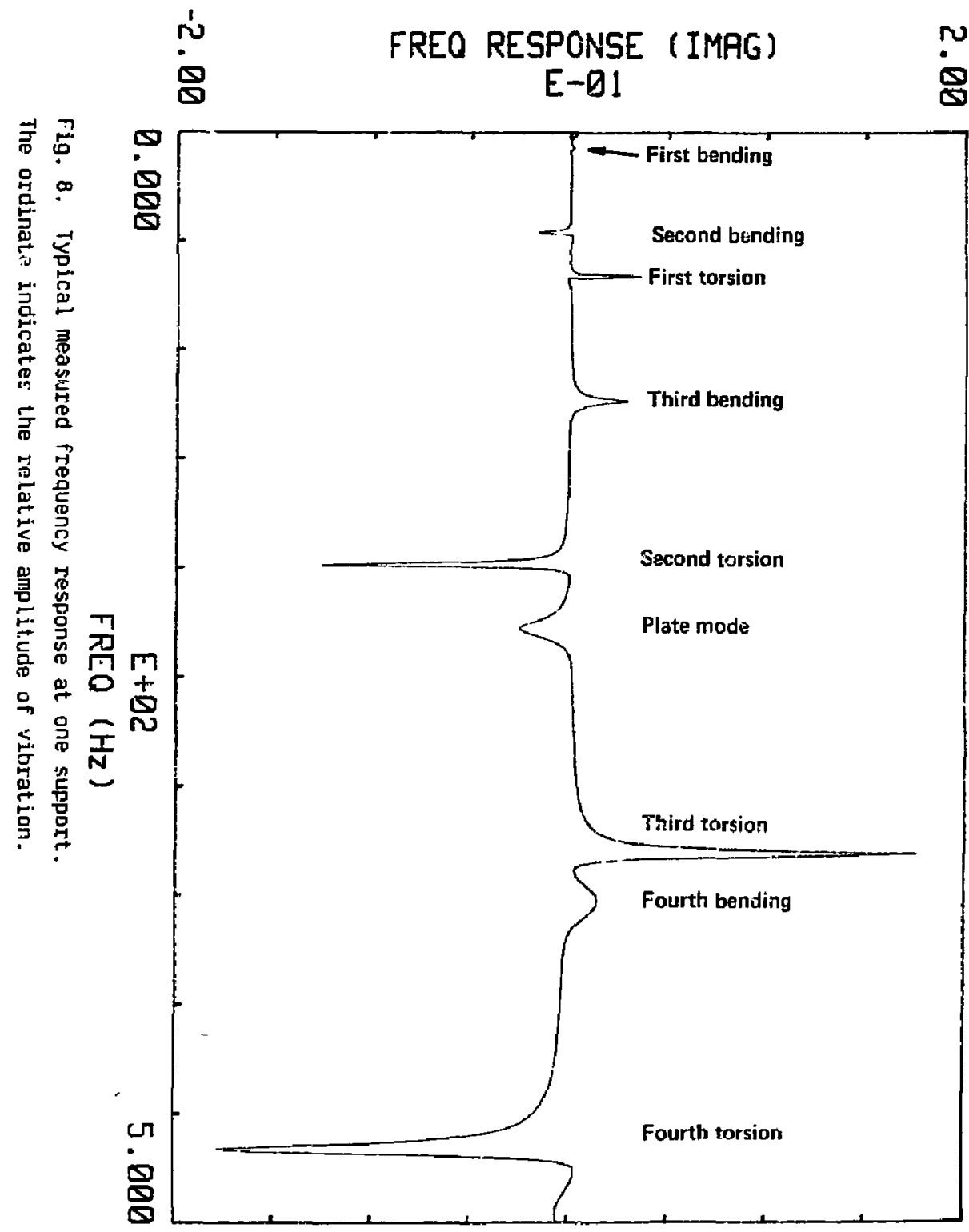




\section{PERFORMANCE}

The performance characteristics of the supports were determined by a modal analysis measurement program carried out after the suppoits were installed. ${ }^{3}$ This program identifies modes of vibration by making a series of frequency response measurements throughuut tine structure; analysis of these measurements then yields a complex eigenvalue and eigenvector for each mode of vibratior. The complex eigenvalue contains the natural frequency and damping value of the mode and the complex eigenvector contains the amplitude and phase of the mode. This characterization provides a mode shape defined spatially over the entire support. for each mode of vibration. The mode shapes along with their eigenvalues completely describe the dynamic properties of the support.

The laser supports have nine modes of vibration in a bandwidth of $0-500 \mathrm{~Hz}$ (see Fig. 8). There are four bending modes, four torsional modes, and one plate mode. Typical shapes are shown in Fig. 9-12. The torsional modes consistently exhitited lower damping levels than did the other modes, thus giving then greater amplification factors. The amplitude of the first bending mode is very small in comparison to that of other modes, as shown in Fig. 8.

Table 1 presents a summary of the first nine modes and their damping coefficients. Also shown on this table are the first three modes as determined by a finite element analysis performed during the design phase. Good agreement exists between the measured and predicted performance.

\section{CONCLUSION}

Following installation of the supports, the mezzanine floor and utility systems were completed as planned. Optical components were welded directly to the supports. Heavier components, such as the large dye amplifiers, were munted to bolts epoxied into the concrete core of the supports. The supports were judged to be an effective and economical approach to mounting a large-scale laser system. 


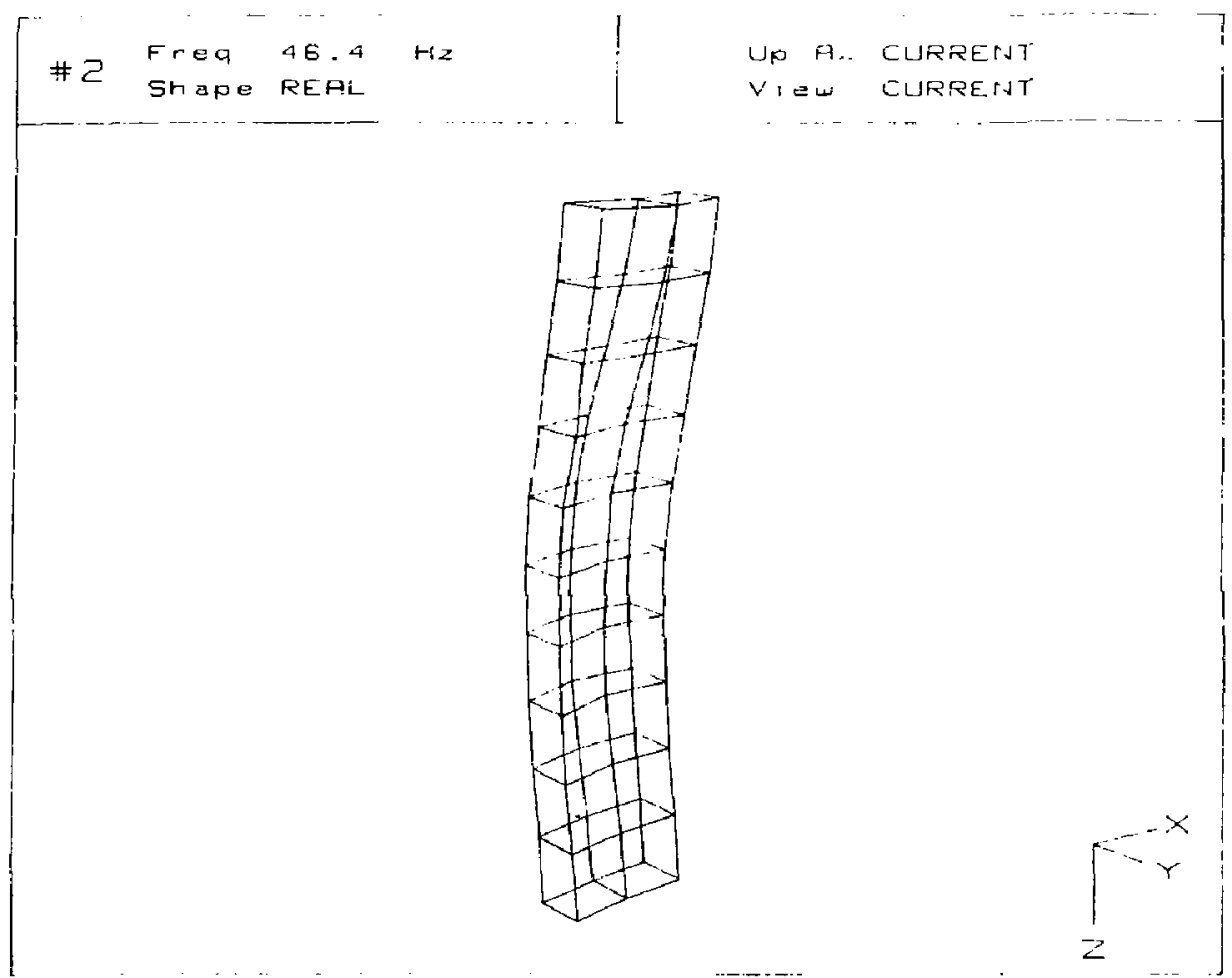

Fig. 9. Typical shape of support when vibrating at $46.4 \mathrm{~Hz}$ (second bending mode). 


$$
\begin{aligned}
& \text { \# Frea E..38 Hz } \\
& \text { Shape PEAl. }
\end{aligned}
$$

Up Ax CLIRRENT

$\because$ IEU CUIRENTT
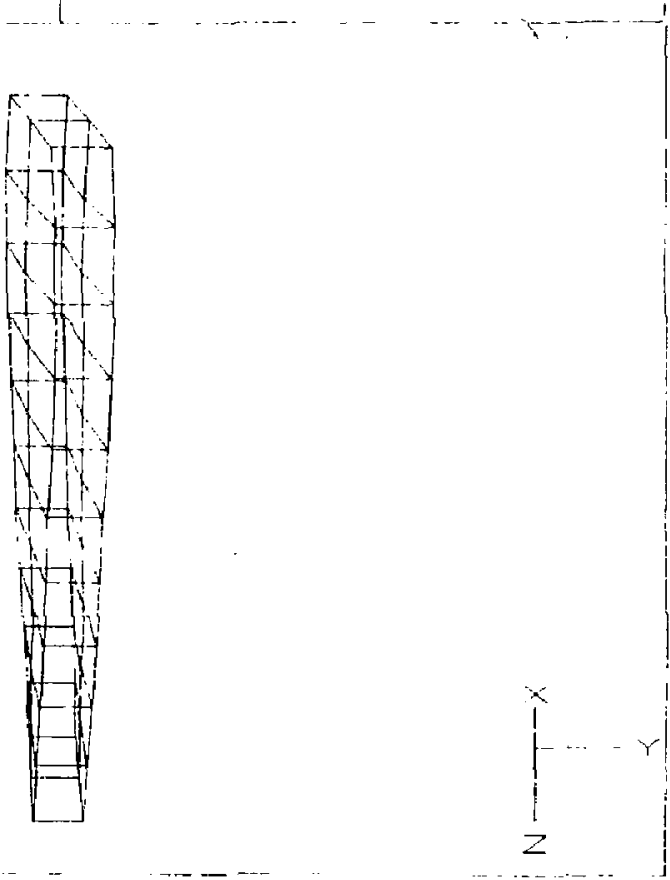

Fig. 10. Typical shape of support when vibreting at $66.38 \mathrm{~Hz}$ (first torsional mode). 


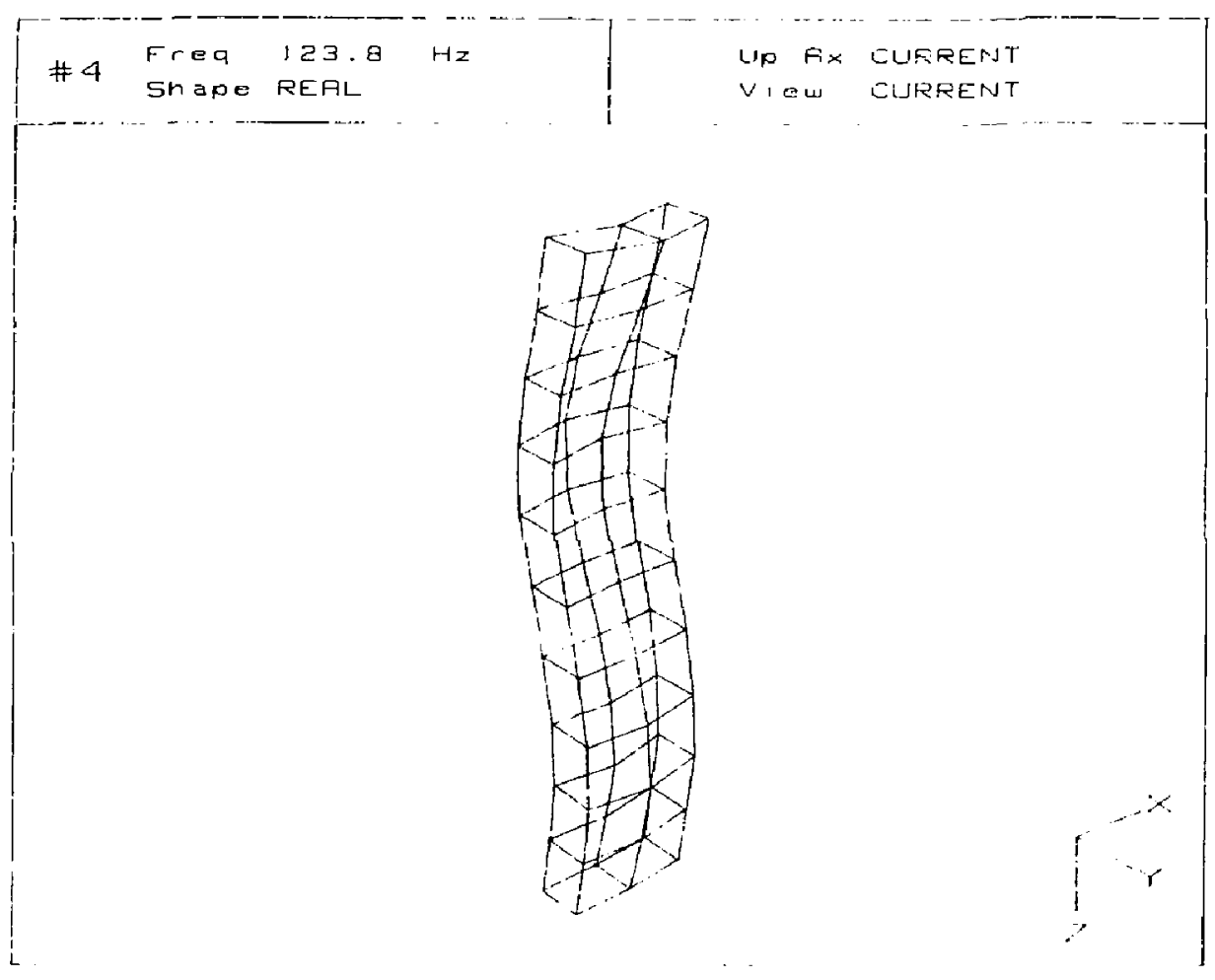

Fig. 11. Typical shape of support when vibrating at $123.8 \mathrm{~Hz}$ (third bending mode). 


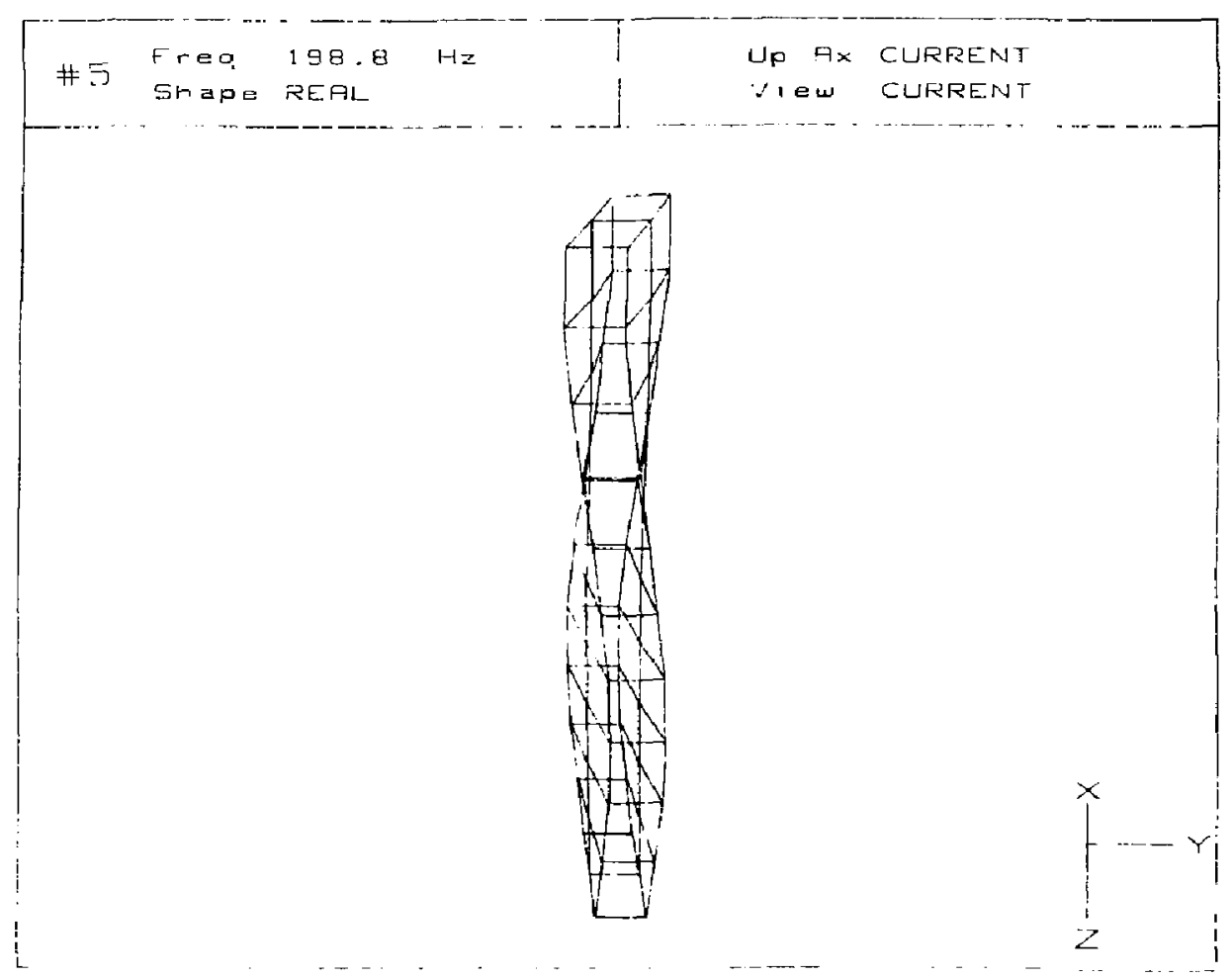

Fig. 12. Typical shape of support when vibrating at $198.8 \mathrm{~Hz}$ (second torsional mode). 
Table 1. Calculated and messured thracteristics of the first nine vibration modes of the supports for optical components in the Laser Demonstration Facility.

Measured Computed

Mode No. frequency $(\mathrm{Hz})$ Damping (\%) Niode shape frequency $(\mathrm{Hz})$

$\begin{array}{lllll}1 & 7.68 & 1.48 & \text { Lst bending } & 7.64 \\ 2 & 46.40 & 1.09 & \text { 2nd bending } & 46.18 \\ 3 & 66.38 & 0.48 & \text { lst torsion } & 60.07 \\ 4 & 123.80 & 1.32 & \text { 3rd bending } & \\ 5 & 198.81 & 0.46 & \text { 2nd torsion } & \\ 6 & 228.24 & 2.10 & \text { plate } & \\ 7 & 331.62 & 0.47 & \text { 3rd torsion } & \\ 8 & 335.10 & 3.04 & \text { 4th bending } & \\ 9 & 467.31 & 0.53 & \text { 4th torsion } & \end{array}$


REFERENCES

1. S. Y. Kim, Structural Calculations, Laser Demonstration Facility, Frederickson Ëngineering Report J-1492, August 15, 1984.

2. R. L. Schwein, SISL Laser SUpport SLructures Test Program, TEI Consulting Engireers Report KR-82239, April 19, 1984.

3. D. Gustaveson, Dynamic Analysis of the Laser Support Structures, LLNL memo to R. Patterson, September 10, 1984. 


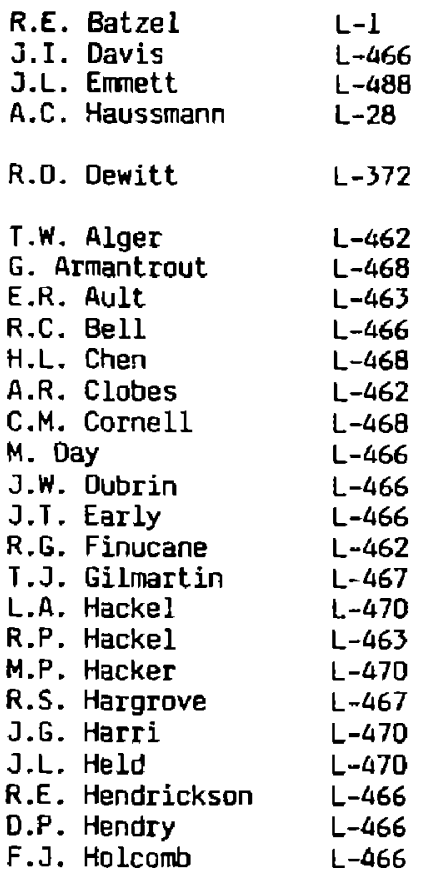

\begin{tabular}{ll} 
J.2. Holtz & $L-459$ \\
M.A. Johnson & $\mathrm{L}-464$ \\
T. Kan & $\mathrm{L}-462$ \\
E.I. Moses & $\mathrm{L}-462$ \\
B.R. Myers & $\mathrm{L}-468$ \\
R.W. O'Neil & $\mathrm{L}-462$ \\
E.F. Oberst & $\mathrm{L}-440$ \\
Y. Oster & $\mathrm{L}-440$ \\
J.A. Paisner & $\mathrm{L}-464$ \\
R.W. Patterson & $\mathrm{L}-462$ \\
C.L. Ponernacki & $\mathrm{L}-443$ \\
R.S. Schechter & $\mathrm{L}-466$ \\
T.A. Shepp & $\mathrm{L}-470$ \\
R.W. Solarz & $\mathrm{L}-464$ \\
M.L. Spaeth & $\mathrm{L}-467$ \\
R.C. Stern & $\mathrm{L}-459$ \\
F.M. Strange & $\mathrm{L}-445$ \\
J.R. Taylor & $\mathrm{L}-443$ \\
R.J. Vetterlein & $\mathrm{L}-441$ \\
A.C. Williams & $\mathrm{L}-468$ \\
J.M. Yatabe & $\mathrm{L}-466$ \\
& \\
T.J. Gilmartin & $\mathrm{L}-467$ \\
Milestone File & \\
J.I. Davis & $\mathrm{L}-466$ \\
CLYA Files & \\
\hline . &
\end{tabular}

TID

$L-658$
(15) 
Mart 1n Marietta Energy Systemis
A.S. Braden
ט.F. Craig
J.P. Forester
C.E. Frye
R.L. Hoglund
C.C. Hopkins
T.J. Huxfora
G.R. Jasny
K. Jarmalow
A.L. Lotts
U.W. McDinald
J.R. Merriman
G.E. Michaels
J.P. Moore
3.E. Owen
J.S. Rayside
J.E. Rushton
T.E. Smith
Martin Marietta
Energy Systems, Inc., $k-25$
Dak Ridge, TN

\section{Department of Energy}

R.E. Dieriam

N. Haberman

J.K. Hancock (Project File)

J.R. Longenecker

J.J. McClure

S.E. Peske

H.M. Polansky

US DOE

affice of Uranium EnTichment

Washington, DC

R.T. Bredderman

US DOE

San Francisco Operations office

Oakland, CA

R.T. Ooten

US DOE

Dak Ridge operations office

Oak Ridge, TN

US DOE

Technical Information Center

Oak Ridge, TN

(27) 